\title{
The Mystical Notion of the Perfect Man

\author{
Discourses of Iranian Revolutionary Painters \\ and the Portrayal of Martyrs
}

\section{Alice Bombardier (Paris)}

As a result of contemporary conflicts, the 1980s onwards sees the emergence of numerous "neo-martyrs" in Middle Eastern countries. In sacrificing their lives, these neo-martyrs demonstrate the merits of their cause and, through their act, sanctify it. The Koran, the Hadiths of the Prophet, and the Imams delineate the martyr canonical privileges, ${ }^{1}$ which include the intrinsic purity of the body and dispensing of all funeral ablution, direct access to upper levels of Heaven without the torments of Purgatory, and the ability to intercede for other men. ${ }^{2}$ As such, neo-martyrs are imbued with paradigmatic force, which is particularly acute in Iran, as martyrdom elevates them to an upper rank of humanity. Falling squarely within this trend, a cult of martyrs was established in Iran in 1979 by the Islamic Republic to extend after death their spiritual and moral influence. Murals or canvas paintings reflecting Islamic-revolutionary norms are key conveyors of this cult. They participate in the commemoration of this privileged category, called by Eric Butel a pantheon of "quasi-saints" given that the Iranian martyr's saintliness is mutilated by its political exploitation. ${ }^{3}$

In 2009 in Tehran, I conducted interviews with several Iranian painters, participants in the Revolution from the outset, as part of a sociological survey on their artistic practices and their representations of art, society, and State. ${ }^{4}$ During these semi-structured interviews, which were conducted in Farsi in the privacy of their workshops, three of these revolutionary artists revealed that they were inspired by the same heroic and mystical imaginative figure. "The Perfect Man" (insān-i kāmil), and to a lesser extent "the Ideal Man" (insān-i $\bar{i} d i b-\bar{a} l$ ), were two denominations emphatically carried by these three painters to designate the artist

1 Denis Gril, "Les fondements scriptuaires du miracle en islam", in: Miracle et Karama, ed. by Denise Aigle, Louvain 2000, 237-50.

2 Eric Butel, "Martyre et sainteté dans la littérature de guerre Irak-Iran", in: Saints et héros du Moyen-Orient contemporain, ed. by Catherine Mayeur-Jaouen, Paris 2002, 307.

3 Ibid, 312.

4 The interviews with Iranian painters to whom I refer here were conducted by me in 2008 and 2009 as part of a PhD research entitled La peinture iranienne au XXème siècle (19112009). Historique, courants esthétiques et voix d'artistes. Contribution à l'étude des enjeux de l'art en Iran à l'époque contemporaine, PhD: Paris/Genève: EHESS/Université de Genève, 2012. The corpus of 19 interviews is available in its entirety in the appendix to the thesis (vol. 2). See "Madame O", 158-61; "Monsieur P", 162-67; "Monsieur R", 168-74. The anonymity of the artists was preserved. 
in his creative process, as well as the new homo islamicus shaped by Islamicrevolutionary values and the notion of the ideal citizen in the Islamic regime.

These three painters clearly shared the same cognitive universe and values. In 1979, they were among the founding members of the Centre of Thought and Islamic Art (harwzih-yi andīshib wa hunar-i islāmin), the artistic and political matrix of the Islamic regime. As part of this work, I will highlight the specificity of the rhetoric that was particular to the Centre of Thought and Islamic Art (CTIA) in the 1980s. This rhetoric, heavily influenced by revolutionary Shiite ideology, was directly inspired by the teachings of Ali Shariati (1933-1977) - an Iranian sociologist whose thought spread primarily through numerous lectures held in Iran from 1965 to 1973. Shariati had a strong effect on the members of the Centre as well as on an important part of the Iranian population. The discourse of the painters is deeply rooted in this rhetoric, which also served to inspire their paintings devoted to the praise of martyrdom. The power of persuasion that this rhetoric demonstrated in the early 1980s in Iran, prompting many Iranians to march to their death, leads to the study of some of its primary characteristics. One of the most important is the recurrent notion of the Perfect Man that stems from Islamic esoteric mysticism.

This study will commence with a presentation of the careers of the three painters in question. From here, I will show how the mystical notion of the Perfect Man was revived by revolutionary Shiite ideology. ${ }^{5}$ In this vein, I will parse out the recurring usages or reformulations of the notion of the Perfect Man present in this ideology. First, in focusing on the painters themselves, an original reformulation of the concept of the Perfect Man linked to the status of artist emerges in their discourse. Moving on to analysis of paintings of martyrs, I will emphasise the parallel drawn in the early 1980s between the process of martyrdom and the spiritual ascent to the Perfect Man. This parallel marks another reformulation of the Perfect Man, here understood as a model for the martyr in which mortality is manifest. Through these plural explorations - semantic, discursive, and iconographic - I will highlight the complex "apparatus" 6 connecting mystical concepts, revolutionary Shiite ideology, and representation, which was established in Iran in the 1980s and which supported these reformulations of the mystical notion of the Perfect Man.

5 By "ideology", I mean a coherent, organised, and epoch-dated system of ideas that explains the existing social order with reasoning based on nature or religion and which serves as a guide to action.

6 By "apparatus", I mean an arrangement of wordings and images required to operate strategically in a given field of forces: "the idea of apparatus ("dispositip" in French) suggests the connection between formal and semantic choices and the set of constraints, conditions, and practices that characterise a given historical situation". Bernard Vouilloux, "Du dispositive”, in: Discours, image, dispositif, ed. by Philippe Ortel, Paris 2008, 31. 


\section{From Artisan to Artist, from the Centre of Thought and Islamic Art to Sürih University: An Initiation Journey}

The three artists highlighted here, Mrs. O, Mr. P, and Mr. R, all present the particularity of hailing from families of craftsmen. All three were able to break with their background as a result of university studies: the success each achieved in the late 1970s in the national competitive exam to enter the Faculty of Fine Arts at the University of Tehran signalled their transition from artisan to artist. This biographical and social data - their modest and traditional backgrounds nonetheless linked to artistic creation - was proclaimed by each as absolutely decisive in their chosen vocation of artist. Indeed, this was mentioned in the first minutes of every interview and explicitly connected to their inclination for painting and art in general. Mrs. O and Mr. P were both born in rural towns from families of weavers and carpet designers who were able to convey to them what Mrs. O called "the taste for the arts" and Mr. P "the power, the capacity to create".

What may have led me to art came from my father and my mother. I grew up in a family where we practiced artistic activities: drawings on carpets. My father drew and my mother wove. My siblings and I, we all developed a taste for the arts. [...] I got a degree of accountancy but I had no desire for it. I wanted to do art. This is why I started university in that field. (Mrs. O, 2009)

The early experience of home life described as particularly warm, dignified, and talented was complimented, according to Mr. P, by the contribution of a pedagogically effective institution ("the library"). A few years after having entered the Faculty of Fine Arts at the University of Tehran, Mr. P participated in the Revolution and, subsequently, became involved in the Iran-Iraq War. Stationed at the front, he contributed to the war effort in his capacity as an artist by portraying the soldiers.

My father was a driving monitor, then he sold tyres. But he loved literature and poetry. He went to the coffee houses, listened to the storytellers and, in the evenings, told us the stories or poems he had heard. He loved poetry, but as he had to bring us up he worked at the bazaar. [...] I often wonder: why did I make these works? [...] I was lucky. What I loved and what delighted me was art. Up to eighteen years old, I wrote plays and played them, especially in the children's library [of my town]. Then I made films. Throughout my childhood, I was making artistic things. I loved tinkering. This is thanks to the atmosphere that prevailed in the library [of the city] where I was born. If this library had not existed, maybe I would never have gone in for a career in art. In this library, I met people who taught me things and told me there was a Faculty of Fine Arts in Tehran. [...]

When I tried the competitive exam of the University, I received first. The best! [in English]. They were surprised because the others had grown up in Tehran while I came from the provinces. It was surprising that a student from the provinces received first at the competitive exam of the University of Tehran. This is due to the fact that for six years I had worked there every day, every day. I was also admitted at the Faculty of Psychology but I did not go. I chose. The inclination for art has perhaps its roots within the human being, then the family comes into the picture, and then the genes. 
I think that in my family there were artistic genes from both sides, from my father and from my mother. My grandmother was an expert in carpet weaving [...]. She had many students. She had the title of "master" in the workshop where she worked. Her husband died very early. She had to bring up her children alone with carpet weaving, all her life. My mother was also a weaver. As a child, I sat next to my grandmother when she was weaving. She sang at the same time very sad songs. Because she had to work hard to bring up her children alone, you know? The voice of my grandmother has always stayed with me. When she would sign and weave. During weaving, the colour yarns would get mixed up. I was asked to separate them. Green on one side, red on the other. And I gave them to the weavers. Maybe by doing this I increased very early my awareness of colours. [...] This was my first experience of creation, that the human being can create things with his hands. The power, the capacity to create from human beings was the lesson my family gave to me, my grandmother in particular.

Then [...] I was accepted at the Faculty of Fine Arts of Tehran. Almost simultaneously, the Revolution occurred. [...] The Revolution [...] ushered me into a professional atmosphere, and finally the war, where I went to the front, all that influenced me. (Mr. P, 2009)

Mr. R, for his part, comes from a family of what can be termed folk painters. He converted the workshop of his father, who practiced Coffee house painting (naqqāshi-i qabrib-khānib), into a museum, in full awareness that he himself was part of an artistic process that started before him and that he had inherited. Mr. $\mathrm{R}$ specified that he received training from the miniaturist Mahmoud Farshchian before entering university. He committed himself wholly to the Revolution, the fervour and the ideals of which he tried to convey during the interview.

My father was a painter. He painted in the coffee house style. He painted religious subjects, the Shāhnāmih, Firdawsī's stories. With the Revolution, the ideals I mentioned appeared. We worked in the Centre of Thought and Islamic Art (hawzih). [...] I was for two years a pupil of Farshchian. Before the university, I was in a secondary school specialised in art (hunaristān). [...] I have studied here for three years. Then I was accepted at the university. After two years, the Revolution occurred. At the time when I was at secondary school, I also worked with my father. (Mr. R, 2009)

In addition to entering the university, the Islamic Revolution of 1979 represented a significant breaking point in the life of these three artists. During the revolutionary period, their activities converged. All three contributed to the founding and functioning of the CTIA. Mr. R described the atmosphere of effervescence that prevailed during the Revolution and the promising sociopolitical context that led to the creation of the Centre.

At the beginning of the Revolution, I was twenty-seven, no twenty-five. We were students at the University of Tehran. At night, we worked in our bedrooms. The Revolution was not victorious yet. Around the university sat the army. They did not know that at night, we lit candles and painted for the Revolution. We were creating posters, paintings. When the Revolution was victorious, we carried all that to Husayniyyih Irshād. [...] We sat in the basement of the mosque (shabistūn), where they settle in winter. There were miles of queues. We called our group "Salmān", from the name of one of the companions of the Prophet. We had borrowed two jeeps from a TV channel with a large truck. We carried our works to other cities. First Qum: it was the first time an exhibition of paintings was held in Qum. People had never seen any artistic exhibition before. And 
Ișfahān, Shīrāz, Ahwāz, Ābādān, Kirmānshāh, Sanandaj, Urūmiyyih, Tabrīz, Gīlān, Māzandarān, Mashhad, Tehran. And the children (bačih-hā, [affectionate term]) got together to found the Centre of Thought and Islamic Art (hawzih). [...] We painted on what I said, on the past, the struggles of the Iranian people, the Shah's regime and on Islam, the ideal society, and the ideal man. I, Hossein Khosrojerdi, Habīb Ṣādiqī, Nasser Palangi... They were numerous. Mr. Halīmī also, but later. Mr. Rajabī. And some women. Students. In the cinema, there was Mohsen Makhmalbaf, you know him in the West. (Mr. R, 2009)

The Centre of Thought and Islamic Art was created as a result of this foundational exhibition of paintings, inaugurated February 11, 1979 in Tehran's Husayniyyih Irshād. In this religious space dedicated to Imam Husayn, Ali Shariati and Mihdī Bāzargān had initiated a series of lectures in 1969, one year after the publication of Ali Shariati's first volume of his major work entitled Islamology (islämshināsī). ${ }^{7}$ This first exhibition of Islamic-revolutionary painting, featuring the social and political struggles of the Iranian people, the struggle against the Shah, the rejection of Western imperialism, and especially the religious and political commitment that culminates in martyrdom, attracted many enthusiastic artists, poets, writers, and filmmakers who rallied to the group, which led to the creation of the multidisciplinary Centre. ${ }^{8}$ Initially non-governmental, the CTIA was attached in 1982 - after the outbreak of Iran-Iraq War - to the Organisation of Islamic Propaganda (sāz$m \bar{a} n-i$ tablighatat-i islämin), opening an era of exploitation by the Islamic Republic of the martyr's figure for the benefit of political and communications strategies. ${ }^{9}$ Also consisting of workshops and exhibition spaces, the Centre left its mark on contemporary Iranian art production by its edicts on the definition and the value of Islamic-revolutionary art and by the exclusive subsidising of artists who subscribed to this creed. It remains above all at the origin of the fundamental pattern of official propaganda, based on the figure of the martyr.

Within the CTIA, the three painters participated in the theorisation of the pictorial Islamic-revolutionary norm, characterised by the overexposure of the martyr's body or its attributes (such as dove and wings), or symbols such as the tulip (lälih). The martyr is the key element of Islamic-revolutionary thought. It is the rallying sign, an identity marker. The quasi-exclusive representation of revolutionary values, the martyr's body in official paintings is a call for political, military, and patriotic commitment. It symbolises the qualities of self-abnegation and self-sacrifice that belong to the ideal citizen as advocated by Islamic authorities. ${ }^{10}$

Almost simultaneously with the establishment of the CTIA, Sürih University, whose artistic orientation exclusively responded to the new Islamic-revolutionary

7 Ali Rahnema, An Islamic Utopian. A Political Biography of Ali Shariati, London 2000, 226-42.

8 Hossein Khosrojerdi, "The Islamic Revolution in Contemporary Iranian Art", in: Tãw ūs, 1 (1999), 91-99.

9 Ziba Jalali-Naini, "L’art islamique révolutionnaire. Naissance et agonie", in: Les cabiers de l'Orient. Revue d'Etude et de Reflexion sur le Monde arabe et musulman, 49 (1998), 125-128.

10 Alice Bombardier, "Iranian Revolutionary Painting on Canvas: Iconographic Study on the Martyred Body", in: Iranian Studies, 4 (2013), 583-600. 
standards, was created within it. This university was among the few that remained open during the political, social, and cultural upheavals in Iran in 19801983. During this period, the academic system was completely paralysed in order to reform programs and teaching: ${ }^{11}$ however, the new institutions created during the Revolution represented an exception and thus remained operational. Sürih University in the CTIA and the new Museum of Martyrs (müzib-yi shubad $\bar{a})$, which included a teaching section led by Dr. Zarinqalam, former director of the Faculty of Decorative Arts, were particularly active. ${ }^{12}$ During these three years of transition, Mrs. O, Mr. P, and Mr. R followed the instruction of Sürih University. After 1983, they went back to the Faculty of Fine Arts at the University of Tehran, but continued to study in parallel at Sürih University. The link woven with this new university remained particularly important as some later chose to teach within its walls.

Between 1980-1983, Sürih University played the role of pilot university in the artistic field. In this capacity, and in keeping with Islamic-revolutionary ideals, new programs, including the painting of martyrs, were developed. These programs spread with the particular intensity of post-revolutionary effervescence, but also within the troubled context of the beginning of the Iran-Iraq War. The dominance gained over the academic system by Sürih University, along with the rhetorical eloquence mixed with ideology of its programs, contributed symptomatically to the emergence of a paroxysmal form of martyr painting. The modality of speaking and painting in a specific language, which was particular to these revolutionary circles and was to be shared first by the group and then by the masses, produced several considerable effects. In a "performative" and persuasive manner, it lent to the act of creation an elevated dimension, close to the divine, and drove into the heart of the Iran-Iraq War through repeated invocations of martyrdom, urging deadly or even suicidal behaviours. This rhetoric, mixed with bloody paintings advocating sacrifice, influenced many Iranians at a loss for points of reference; as shown by the sociologist Farhad Khosrokhavar, this almost forced them down a "martyropathic" process to self-sacrificial violence. ${ }^{13}$

As of 1981, among the circle of committed artists who attended this new university, many were promoters of this Islamic-revolutionary form of painting with its deadly overtones. At that time, some of these works were even published as postcards by the Organisation of Islamic Propaganda. Reproduced and distributed in number, these paintings were representative of a "dead-conveying Shiism" 14 developed in the second year after the Revolution, with Sürih Univer-

11 See Bombardier, La peinture iranienne au XXème siècle.

12 Alice Bombardier, "La peinture murale iranienne: genèse et evolution. Enjeux de la spatialisation artistique dans le processus d'affirmation et de pacification des pays du MoyenOrient”, in: Standing on the Beach with a Gun in my Hand. Eternal Tour 2010 Jérusalem, eds. Noémie Etienne and Donatella Bernardi, Genève-Paris 2011, 119-20.

13 Farhad Khosrokhavar, Lislamisme et la mort, Paris 1995, 26-30.

14 Ibid, 37. 
sity steering the theorisation and spread of their rhetorical and pictorial form. I will refer further to some of these pictorial reproductions in order to better understand the impact of the idea of the Perfect Man on painting of martyrs in Iran.

\section{The Mystical Notion of the Perfect Man and Revolutionary Shiite Ideology}

The notion of the Perfect Man has long been a reference for Persian miniaturists, which perhaps partially explains its success among revolutionary painters. According to Mehdi Mohammad-Zadeh, faces of Shiite saints in Persian miniatures are unique in their portrayal of similar or even identical features corresponding to the face of the Perfect Man. ${ }^{15}$ "The Imam", stated the Prophet, "is the person who physically and morally most resembles me" and "his portrait is mine". ${ }^{16}$ Mohammad Ali Amir-Moezzi confirms that the notion of the Perfect Man is rooted in the figure of the Imam as conveyed by the oldest Shiite sources. ${ }^{17} \mathrm{~A}$ tacit agreement was thus adopted among the miniaturists to represent the saints with a featureless face, as was commonly accepted in religious literature.

The idea of the Perfect Man was especially developed in the theosophical writings of Andalusian Sufi thinker Ibn al-'Arabī (1165-1240). ${ }^{18}$ Henry Corbin, in Cyclical Time and Ismaili Gnosis, writes about the following development of the concept in earlier stages of Ismā cili Shiism, wherein the Gnostic idea of the Imam as "Perfect Anthropos" prevailed. ${ }^{19}$ In Shiism, where the esoteric dimension of Islam is highly developed through Imamology and the theology of wilayat (divine friendship, later rendered "power" in the doctrine of Ayatollah Khomeini), a spirituality close to Sufism occupies a substantial place and is bolstered directly with great Sufi works including those of Ibn al-'Arabie. ${ }^{20}$ It must be noted, however, that Sufi doctrine as such is criticised in Iran by the Shiite clergy, who perceive it as illegitimate in the context of doctrinal competition. Many Shiite 'ulam $\bar{a}$ ' denounce the non-compliance of Sufis with the doctrinal and social rules of Islam. Indeed although the obligations of Islamic worship (prayer, fasting, pilgrimage, ritual almsgiving) are not abolished, they are none-

15 Mehdi Mohammad-Zadeh, Liconographie shiite dans l'Iran des Qadjars. Emergence, source et développement, PhD: Geneva-Paris: University of Geneva-EPHE, 2008, 35.

16 Shaykh Șaddūq, Ikmāl al-dìn wa itmām al-ni'ma, vol. 1, 286. Quoted in Mohammad-Zadeh, L'iconographie shiite dans l'Iran des Qadjars, 35.

17 Mohammad-Ali Amir-Moezzi, Guide divin dans le shiisme originel, Paris 2007.

18 Prior to Islam, the origin of the notion of the Perfect Man can be compared to Gnostic conceptions, which took many forms before converging in the Manichaeism with the doctrine of the First Man. According to the disciples of Zoroaster and Mani, this prototypical man has to fight evil and darkness. Roger Arnaldez, "Al-Insān al-Kāmil”, in: Encyclopédie de l'Islam, Leiden et al. 1971, 1271.

19 Henry Corbin, Temps cyclique et gnose ismaélienne, Paris 1982, 57-8.

20 Yann Richard, Le Shicisme en Iran: Imān et révolution, Paris 1980, 93. 
theless secondary in this cult reserved for initiates. ${ }^{21}$ This is why Shiite theologians in Qum prefer the term "gnosis" ('irfän) rather than "Sufism" (tașawwenf) to denote the commonalities existing between Shiism and Sufism. ${ }^{22}$ Yet, according to Henry Corbin, various Shiite thinkers, mostly Siyyid Haydar Āmulī (born c.1320), Ibn Abī Jumhūr (born c.1401) and Șā’in al-Dīn 'Alī Turkih Iṣfāhānī (died c. 1426-1433), who wrote a comment on Ibn al-'Arabī's Fușus al-Hikam (Gems of Wisdom), were interested in the concepts developed by Ibn al-'Arabi and integrated some aspects into Shiite dogma. ${ }^{23}$

Philosophical, religious, and moral, the notion of the Perfect Man was notably reinvigorated in the twentieth century by Muhammad Husayn Ṭabātabā'̄i (19031981). In his widely circulated book, The Principles of Pbilosophy and the Realistic Method, Tabātabā'ì advocates a spiritual philosophy. ${ }^{24}$ Ayatollah Khomeini (19021989) himself, who taught mysticism and philosophy at Qum until the early 1950s, referred to the doctrine of the Andalusian Sufi. ${ }^{25}$ However, Ali Shariati differed from his predecessors by giving to the notion of the Perfect Man a social, political, and ideological dimension. A sociologist committed to the religious opposition of Mohammad Reza Shah Pahlavi's regime, and considered one of the major ideologues of the Islamic Revolution, Ali Shariati was influenced both by nationalist and religious circles. He studied in Mashhad, then in Paris between 1959 and 1964; on his return from France, he attempted to reconcile his Western education with the religious beliefs of his country. Shariati conceived a new Islamic idiom, putting emphasis on the social and political dimension of Islam, which he expounded upon in 1968 in the first volume of his major book, Islamology (islämshināasi), then again in 1973 in a second volume. ${ }^{26}$ Between 1969 and 1973, Ali Shariati also conducted lectures that benefited from a wide audience in the conference centre he founded with Mihdī Bāzargān in Husayniyyih Irshād. These lectures prompted his arrest by the political police of the Shah, as well as that of many of his students; Shariati spent eighteen months in prison. After being released in March 1975, he was allowed to go into exile in England, where he died shortly after his arrival and a few months before the outbreak of the Revolution. His ideas largely influenced the revolutionary fighters and the new regime that was established during the Revolution.

According to Ibn al-'Arabī, the idea of the Perfect Man - whose primary meaning is "prophet" or "vicar of God on earth" in the Koranic verses of Light (IX, 32

21 Yann Richard, L'Islam chi'ite: croyances et idéologies, Paris 1991, 76.

22 Henry Corbin, En Islam iranien, I, 11; III, 153. Quoted in Richard, L'Islam chi'ite, 81.

Muhammad Husayn Țabātabā'̄î̀, Usul-i falsafỉ wa rawish-i riātism [The principes of philosophy and the realistic method], ed. by M. Muțahharī, 5 vol., Tehran, 1953-54; Shicite Islam, trans. S. H. Nasr, Albany 1975.

26 Ali Shariati, Islamshināsī, vol.1, Tehran 1968; vol. 2, Tehran 1973. 
and LXI, 8$)^{27}$ - was above all understood as a symbol of the human being, the ontological meaning of human existence that the thinker chose to illustrate with the figure of the first man, Adam. ${ }^{28}$ In the opinion of Masataka Takeshita, the Perfect Man in Ibn al-'Arabï's philosophical treaty Fușuss al-Hikam could also refer to the figure of the Gnostic Sufi who had reached the upper threshold of his mystical journey, the possessor of divine knowledge (marifa) who sees the appearance of the Divine Names in all forms of earthly existence. ${ }^{29}$ By this ability, the Gnostic Sufi is the only one in Ibn al-'Arabī's treaty, according to Takeshita, who can be called "human being" in the true sense of the term.

After 1969, one of Ali Shariati's lectures delivered in Husayniyyih Irshād was 'Ali, the Perfect Man. ${ }^{30}$ The idea of the Perfect Man, as elaborated upon by him in the contemporary era, was henceforth inseparable from the Shiite spiritual tradition. By reinterpreting in a decidedly militant fashion the founding principles of Shiism, Ali Shariati wanted to transform Islam into a progressive, liberating, and revolutionary religion. In the first volume of Islamology (islämshināsī), several pages are also devoted to the Ideal Man, the "theomorphic man in whom the spirit of God has overcome the half of his being". ${ }^{31}$ The reference here is thus not to the Imam 'Ali but rather is understood in a broader sense as every man encompassing the qualities of "truth, goodness and beauty - in other words, knowledge, ethics and art". ${ }^{32}$ These writings had particular influence on the revolutionary youth ${ }^{33}$, who could easily identify with this Ideal Man and adapt the mystical idea of the Perfect Man to the socio-political realities of contemporary Iran. The description of the human qualities of the Ideal Man - "pure" and "pious", whose heart is dedicated to the inner life and the mysteries of the spirit but whose body participates in the struggle for freedom - is followed by an illustration of his lifestyle based on stories recounting the lives of the prophets.

Following these parables, Ali Shariati's reflections on art, which he argued must be used as a creative tool in the hands of the Ideal Man and not as a "toy", 34 deserves to be highlighted. The attention he turned to the virtues of art in the context of Islam and mystical philosophy was new:

27 Arnaldez, "Al-Insān al-Kāmil”, 1271.

Masataka Takeshita, "The Theory of the Perfect Man in Ibn 'Arabī's Fuṣuṣ al-Hikam”, in: Orient 19 (1983), 91.

29 Ibid, 95-97.

30 Ali Shariati, On the sociology of Islam. Lectures by Ali Shariati, trans. Hamid Algar, Berkeley $1979,35$.

31 Ibid, 121.

32 Ibid, 124.

33 A slogan that could often be read on banners in protest marches during the Iranian Revolution also came from Ali Shariati's work Shahādat: "Karbalā' is everywhere; every month is Muharram; every day is ' $\bar{A} s \bar{u} \bar{u} \bar{a}$ ”, Ali Shariati, Shabādat, Tehran 1972, 104. See Heinz Halm, Shic Islam, Princeton 1997, 136.

34 Shariati, On the sociology of Islam, 123. 
Art is not a plaything in [the] hands of [the Ideal Man]; it is not a means for gaining pleasure, for diversion, for stupefaction, for the expenditure of accumulated energy. It is not a servant to sexuality, politics, or capital. Art is the special trust given to man by God. It is the creative pen of the Maker, given by Him to his vice-regent so that he might make a second Earth and a second paradise, new forms of life, beauty, thought, spirit, message, a new heaven, a new time. ${ }^{35}$

The artists who converged on the CTIA clearly founded the renewal of their status along these lines. It allowed them to present themselves as life guides and justified the new educative, religious, and political mission they sought. For this group of artists, such philosophical underpinnings translated into the assertion of their importance in the transmission of the new Islamic-revolutionary values and legitimised their profession.

In support of the same mystical tradition as his predecessors, Ali Shariati popularised in Iran the use of the word "ideology", understood as a body of doctrines inspired by religious beliefs but guiding social and political action. Shariati clearly distinguished Islam as an ideology, in the sense of active enforcement of beliefs, from Islam as a religious culture preserving tradition. He claimed that it was in the principles of Islam to link religion and politics. This use of the term "ideology" was reconfirmed by the authorities of the Islamic Republic, who adapted the notion to establish what became Shiite revolutionary ideology. If Shariati praised the human, moral, and religious merit of the Ideal Man in an ideal society (the umma according to him), ${ }^{36}$ the Islamic regime went one step further by exploiting the principle of the Perfect Man - and through him the martyr - to achieve its aims of internal consolidation. The various usages of the mystical notion of the Perfect Man, which heavily influenced the discourse of the CTIA painters, are an exemplary illustration of the Islamic regime's ideological reformulation of a spiritual legacy in the service of its own interests. Indeed, the Islamic regime diverted from their original context the fundamental principles on which the authority of the Imami religion is based. The revolutionary Shiite ideology, derived from these reformulations, led the Islamic regime to significantly increase its political, social, and economic influence, which reached its peak in the 1980s. The painting of martyrs, which expanded throughout this period, is among the most effective expressions of this ideology. This ideological influence was still perceptible in 2009 in the discourse of the revolutionary painters interviewed here.

\section{The Resurgence of the Notion of the Perfect Man in the Discourse of Revolutionary Painters}

In 2009, thirty years after the Revolution, the discourse of these three painters maintained a strong ideological tone that reflected the teaching of the CTIA and

35 Ibid, $123 f$.

36 Ibid, 119-20. 
its satellite, Sūrih University, as evidenced by their somewhat scripted shared formulations. The Persian term "Hawzib", which designates the CTIA, literally means "Islamic school". Within this religious school dedicated to art, Ali Shariati's writings and teachings occupied a central position and were implemented through the principle of "revolutionary self-training" as defined in the early pages of Islamology. ${ }^{37}$ Revolutionary self-training consists of developing a person's potentialities in close relation to his social and political context. As stated by Nouchine Yavarid'Hellencourt, "Revolutionary self-training according to Ali Shariati, it is to rise up in a revolutionary manner, it is to accept a fundamental principle, to adhere to a noble goal which is none other than the determination to move towards man's existential perfection. Revolutionary self-training is for Shariati what allows to rise up just like Ali." ${ }^{38}$ It is thus not surprising that the notion of the Perfect Man is so deeply engrained in the minds of these three painters, who referred repeatedly to it during the interviews. This notion is used not only in the sense of Shariati in Islamology (i.e. the ideal of the pious man seeking godly perfection in intellectual and political struggle) but also in the more specific context of the artist group as a form of self-justification or sanctification of their mission. Indeed, celebrated by Ayatollah Khomeini, ${ }^{39}$ the ideologically committed artists were key players of the Revolution. ${ }^{40}$ In this vein, Mr. R uses of the term "Ideal Man", as directly inspired by Shariati, to describe the content of the works presented at the founding exhibit of Husayniyyih Irshād.

Yes, the first event of the Revolution was pictorial. We painted on what I said, the past, the struggles of the Iranian people, the Shah's regime and Islam, the Ideal society and the Ideal man. (Mr. R, 2009)

In line with Shariati's teachings, the Perfect Man is mobilised by Mr. R to establish a new scale of values within Iranian society. During the interview, Mr. R conveyed the force that drove the actors of the revolutionary utopia in its original purity. Mr. R explicitly associated the notion of the Perfect Man with the Iranian Revolution, thus conferring a sacred dimension on the political event. According to him, the notion of the Perfect Man is the future promise of a reconstruction of post-revolutionary society via mysticism. The Perfect Man is equivalent in his discourse to the ideal citizen of the Islamic Republic, "where everything is centred around God". In other words, the bomo islamicus that Mr. R - along with many Iranians involved in the Revolution - hoped would finally be embodied.

The ideals of the Revolution... Well, I... I was... a painter of the Revolution. I believe in these issues. Everyone believes in something. Men pursue ideals. Worldwide. Our Revo-

37 Ali Shariati, Histoire et destinée, trans. F. Hamed and N. Yavari d'Hellencourt, Paris 1982, 38.

38 Ibid, 38.

39 Agnès Devictor quotes a declaration of Ayatollah Khomeini defending cinema and filmmakers, who "bring up the people". Agnès Devictor, Politique du cinema iranien, Paris 2004, 24.

40 The story of the Revolutionary events made by Mr. R and also quoted above, gives a concrete image of what these artists undertook, especially in Qum where no art exhibition had never reached such a scope. 
lution had two ideals, which were derived from Islamic past culture, actually the Iranian culture: to achieve the Perfect Man, and that the society becomes perfect too. A perfect society is a society that has pure human and divine ethics. That is the time of justice, spiritual love, and kindness and where everything revolves around God. For example, in the centre of a circle, there is a point. We say that this central point is God. So all behaviours that exist in a society must be linked to God. In the Shiite belief, when the Imam of the Time returns and calls the end of the world with his horn, this event occurs. Its base becomes God. The foundation becomes the contentment of God. The morality of men becomes respect for God, piety. Do you know what that means? Respect for God, it means a behaviour without sin. Morality becomes divine.

With these words, Mr. R gives access to the inner mystical dimension of human experience that he lived during the Revolution: through the experience he was; it transported him and caught him in a collective movement of total commitment. In this lived experience, he and the "children of Hawzib" (hinting at the members of the CTIA), as well as the Iranian people as whole, seemed to be within reach of the Perfect Man. For him, the Revolution was an event that ushered in a new era. He legitimised his "ideals" by referring to the "Islamic past culture" and "Shiite belief".

More unexpectedly, and perhaps more specifically to the circle of committed artists who attended the CTIA in the early 1980s, two of the painters also referred repeatedly to the notion of the Perfect Man when they evoked their own artistic careers. In their eyes, the Revolutionary artist does not content himself with simply conveying the ideal of the Perfect Man in pictorial representations; rather, it is embodying the Perfect Man in his own life as an artist that is also essential. In line with what Ali Shariati wrote on art as an instrument in the hands of the Ideal Man, the painters asserted that the revolutionary artist devotes himself to the creation of an artwork - which places him equal to God through his creative act - while at the same time rendering his own life an artwork.

Similarly, Mr. P drew his inspiration directly from the doctrine of Ibn al'Arabi to define the artist worthy of the name. The human faculties that Mr. P mentioned at the beginning of the interview (extract below) refer to the twentysix perfect behaviours defined by Ibn al-'Arabī in Fușuss al-Hikam. These perfect behaviours, according to Ibn al-'Arabī, must be developed by man over the various paths that lead to perfection. Ibn al-'Arabi described in detail these paths and faculties, embodied by legendary prophets. Along with these faculties, Mr. P emphasised the need for mystical elevation. This kind of knowledge can be linked to ma'rifa, the upper branch of knowledge in the doctrine of Ibn al-'Arabi. Moreover Mr. P used the terms of the latter to describe how one should proceed to move closer to perfection: the artist must open the eyes of the heart (qalb), which are reason ('aql) and imagination $(k b a y \bar{a} l) .{ }^{41}$

41 William C. Chittick, "Ibn al-'Arabī”, in: Encyclopedia of Islam and the Muslim World, ed. by Richard C. Martin, New York 2004, 333. 
It is complicated and long to define what is a true artist but in a few sentences, I would say it is someone who is himself. Who sees what he likes. We are wearing masks. The artist knows himself. He transforms his individuality in creation. Strength, which becomes creation, is in man himself. Man must develop these faculties: imagination (khayāl), reflection (tafakkur), sensitivity (ihsās), intelligence (ta ${ }^{`}$ aqqul), thinking (wahm), inspiration (ilhām)... The man who develops these faculties becomes a Perfect Man. Otherwise he sleeps and eats, that is all. The artist is a man who knows his inner energy and uses it so that it becomes art: music, painting...

I accept also the mystical vision. I think many works that are shown are only technical works. But I think that spirituality and art are one. Someone who has a mystical vision of things is also an artist. Without that, he is only a technician. Only skilful. The ordinary person sees with the eyes of the head, he has only a vision of physical things. A vision somewhat higher comes from the beholder of the mind's eye. The third eye is the eye of the heart. Mystics have this third eye. [...]

I think an artist is someone who sees from three eyes: head, mind, and heart. He is awake, open, he sees. In the mystical culture, we say bașirat (voyance, insight, intelligence). Hāfiz and Mawlānā say: șāhibnazarar (perceptive, lucid). [...] One of the conditions to be an artist is to have the third eye. [...] (Mr. P, 2009)

In these words, the contradiction between the Ideal Man, an artist who has faculties moving him closer to divine wisdom and towards the Perfect Man, and the man who, according to the painter, "eat and drink, that is all", is radical. This allusion to a man concerned only with basic needs, placed at the bottom of hierarchy by Mr. P, can be compared to the idea of Animal Man developed by Ibn al'Arabī as a counter-model of the Perfect Man.

The same inspiration is visible in the discourse of Mrs. O. Her comments can also be compared to the writings of 'Abd al-Karìm al-Jìli (1366-1424). Upholder of Ibn al-'Arabī's thought in the fourteenth century and author of The Universal Man, 'Abd al-Karìm al-Jîlī presumed that the Perfect Man is the pole around who turn all spheres of existence, from the first to the last. ${ }^{42}$ According to Mrs. $\mathrm{O}$, an artist must "improve all the dimensions of his life".

A true artist is a Perfect Man. A human being who manages to make perfect the four dimensions of life: his soul, his body, his mind, his heart. An artist is not just someone who paints well, writes well... This is someone who has an elevated soul, a soul full of kindness. Who knows public relations. Who has good friends. Kindness is part of his art and his language. This is a man who improved all the dimensions of his life. He can talk, make friends, laugh, cry. The dimensions of his existence becoming perfect are reflected in his art. If he is an accomplished man, all he does is artistic. If he paints, he paints artistically. Artists are Perfect Men who have a perfect existence. (Mrs. O, 2009)

Beyond this, Mr. P also specified that the link existing between the artist and the Perfect man is etymologically inscribed in the Persian language itself: "Hunar (art) comes from Sanskrit: $b u=k \bar{a} m i l$ (perfect) and nar $=i n s \bar{a} n$ (man). At first, they said sunar in old Persian language. Then, it became bunar.” (Mr. P, 2009)

42 Arnaldez, “Al-Insān al-Kāmil”, 1272. 
According to Mr. P and Mrs. O, art constitutes in itself a way to perfection. Stemming from these ideological and doctrinal positions, art is from then on presented by them as a means to access truth and transcendence. For these painters, the relationship with God comes no longer directly under spiritual guides (Imams) or human guides (mystical poles, or qutb in the Sufi congregations), but through the individual's search for the "Imam of his being", the Perfect Man potentially existing in each person that art has the power to help uncover. This viewpoint gives a new stature, both missionary and paradigmatic, to the revolutionary artist: the mission of the artist is sanctified and his status is significantly increased. This reference to mystical tradition inserted artistic practice into the new Islamic regime by rendering it praiseworthy and attractive, but also by submitting it to the ideology of the latter, and if necessary, by using it as a political instrument.

The comments of these painters regarding the deeply rooted notion of the Perfect Man hint at the reformulations at play in the early 1980s in revolutionary Shiite ideology, as well as their implications. The reading of Ali Shariati constituted a significant theoretical foundation that allowed these newly formed artists exposed to modernity to fully come to terms with their vocation without losing their traditional identity of persons of faith.

\section{The Influence of the Notion of the Perfect Man on the Painting of Martyrs}

At the beginning of the Iran-Iraq War, between 1980 and 1983, when most of the revolutionary painters practiced their art at the CTIA and followed classes at Sürih University, the figure of the martyr became omnipresent in their works. Perhaps as a result of the people's growing distress in witnessing the misconduct of the Revolution and its sacred utopia, ${ }^{43}$ much of the murals and canvas paintings attested to increasingly doleful representations of martyrs reaching a point of martyropathic escalation.

Analysis of paintings produced at this time by the CTIA revolutionary painters demonstrates how each proceeded to represent the martyr. ${ }^{44}$ Through descriptions of the works, I will highlight what is conveyed in these paintings and how the concept of the Perfect Man spread within the CTIA, and in turn how this is connected to the representation of martyrdom. Printed by the Organisation of the Islamic Propaganda in the early 1980s, four paintings are analysed. ${ }^{45}$

In the first painting, martyrdom is in progress. In Submission to God (qunüt) (c.1981, see fig. 1), Hossein Khosrojerdi portrays an ethereal and evanescent

43 Khosrokhavar, L'islamisme et la mort, 26-30.

44 See also Bombardier, "Iranian Revolutionary Painting on Canvas", 583-600.

45 See Khosrokhavar, L'islamisme et la mort, 288-303. Khosrokhavar carried out a socioanthropological analysis of some of these postcards. 


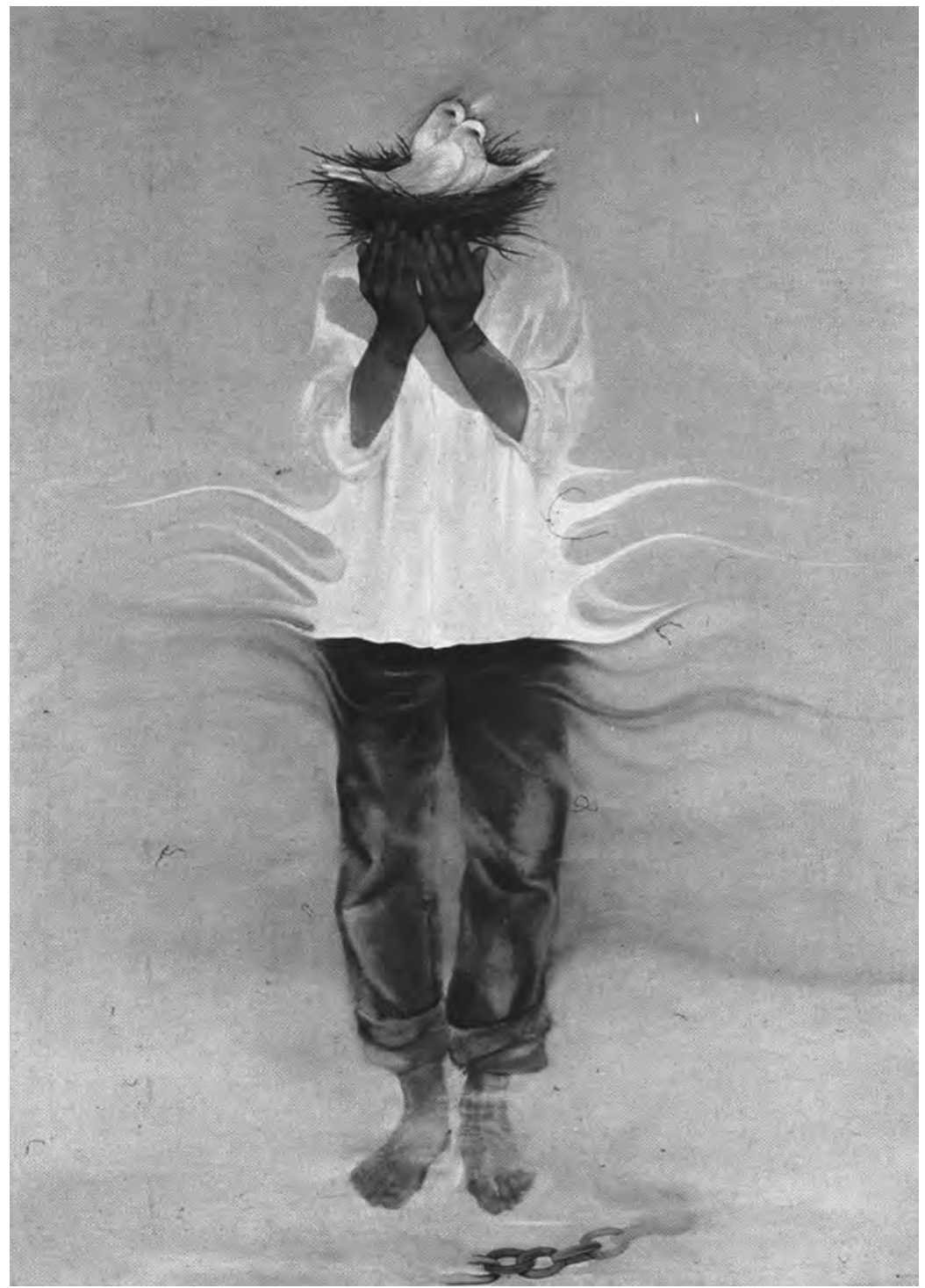

Fig. 1: Hossein Khosrojerdi, Submission to God (qunūt), c.1981 $(170 \times 120 \mathrm{~cm})$

man, a mirage on the edge of the living world, standing in a pose of prayer (open hands covering the face). He is wearing green trousers, the colour of Islam, rolled up mid-calf and revealing a red lining. The top of the trousers, whose sides seem to be going up in smoke, his hands and wrists, as well as a nest in place of the head where two doves are nestled, are all glowing as if ready to burn out. This man is standing with his bare feet joined, floating in a pure white haze. His shirt is also white, fraying on both sides. His face is absent, as his entire head is overshadowed by the pair of nestling doves standing in place of his spirit. The posi- 


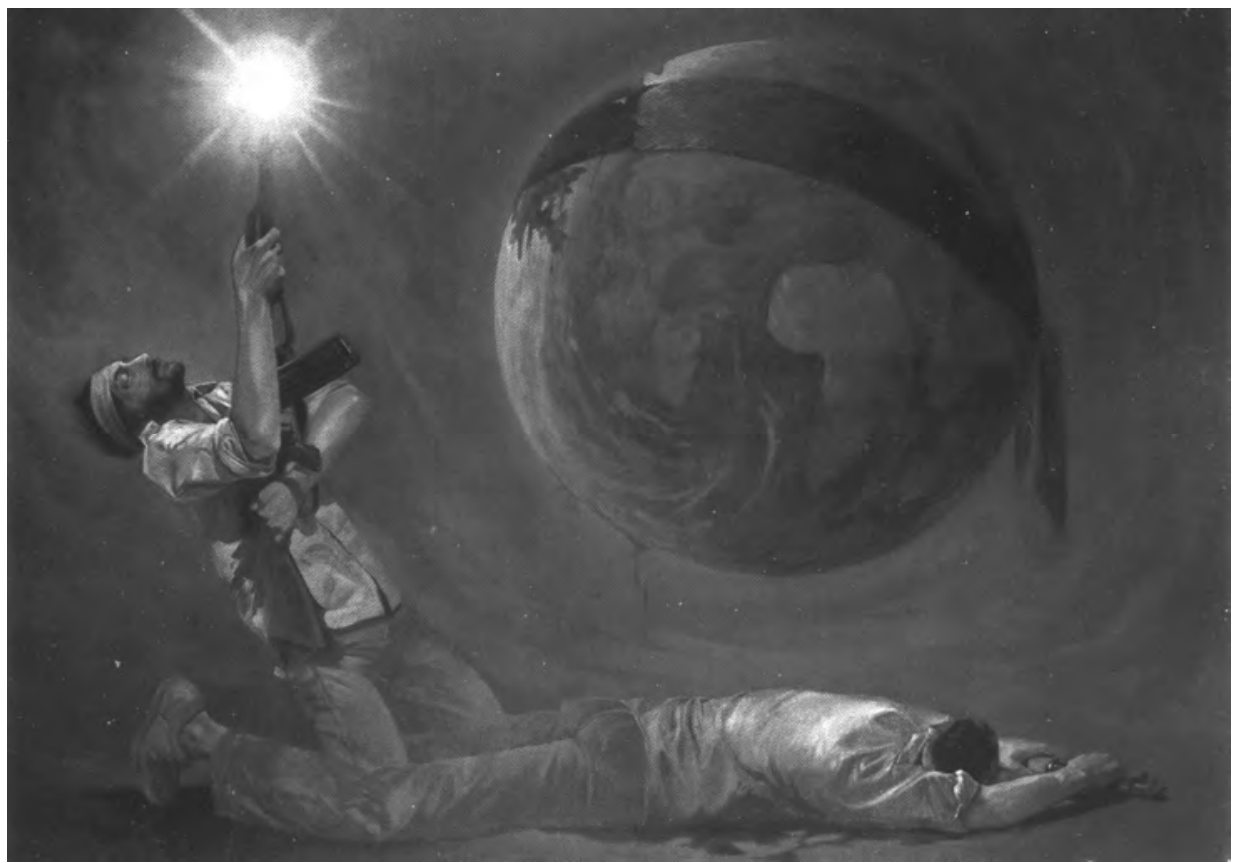

Fig. 2: Hossein Khosrojerdi, Light of History, c.1981 $(160 \times 130 \mathrm{~cm})$

tioning of the two birds is well balanced and harmonious, with their eyes oriented in the same direction.

The yearning for martyrdom has eclipsed all other thoughts. The painter insists here on the call of Heaven, the need for this man on the path of transmutation to free himself from the chains of existence, which now lie on the ground but remain enclosed before his ankles. Martyrdom and prayer are juxtaposed. The yearning for martyrdom seems to consume the man from inside. The two peaceful doves cover (or mask?) his feelings and symbolically represent that for which he yearns.

In Light of History (c.1981, see fig. 2), another painting by Hossein Khosrojerdi, the martyr is represented at the moment of his killing.

Two men in uniform - or rather, two postures of a single man, their legs intertwined - occupy the foreground. The persuasive power of the work is enhanced by the use of a figurative and scaled narrative, featuring a body in motion. The body is split in two to represent two key steps it goes through. First kneeling, the soldier is shown like someone in prayer ready to bow down, in an pose that seems to represent the step of the "liberating explosion" 46 of martyrdom, symbolised by the flash of light flowing from the gun. Death is considered equivalent to

46 Terms used in the wills of Iranian martyrs of Iran-Iraq War. See Eric Butel, Le martyr dans les mémoires de guerre iraniens. Guerre Iran-Irak (1980-1988), PhD: Paris, 2000, 521. 
mystical ecstasy. The second moment of death is depicted by the soldier who has fallen forward. This is the time of the settling, experienced as the liberation from the body, rendered an empty shell. Face against the ground, the soldier remains braced with both hands on his rifle, which he keeps on holding at arm's length. When moving towards death, the kneeling soldier is serene, disconnected from his suffering. Yet, he is wounded: under the rifle he hugs, blood is flowing. This fighter is already removed from the world. He faces Earth, which is humanised, transformed into a head with a green band tied around the forehead, which Iranian soldiers wore before attacks and which the fighter also sports. Paralleling the fighter, Earth is also injured and bleeds from under the headband. This earth, which symbolises the desire for unity and totality of the soldier society, is not represented as a dead or inert substance but rather as a source of vital strength. This is a sphere impregnated with supernatural power. Changing the scale of the earthly creatures and of the space that encompasses them allows for the representation of a new world, to be shaped by metaphysics. The work is entirely painted through a filter of blood, whose red colour covers even the green of Islam in the uniforms and headbands.

Death is directly conjured up by the injured body, lying lifeless. In this way, violence is fully sublimated and thus converted into a mystical ecstasy. The soldier's weapon constitutes his injury, killing, martyrdom, and ecstasy (as depicted by the light emanating from the gun). Although death is present, it is reinterpreted as the mystical experience of martyrdom, which is announced by the posture of prayer. As such, martyrdom and prayer are once again superimposed. The enemy is not designated nor are the circumstances that justify the battle; nonetheless, another actor is visible: the Earth, which also fights and bleeds. The painting's title, for its part, evokes a guide leading the path.

The two remaining paintings invoke the aftermath of martyrdom.

Nasser Palangi's Shroud of Blood (c.1981, see fig. 3) portrays a minimalist representation of martyrdom. Interdependent bloody shrouds placed side by side in several rows - expressing some type of collective - symbolise the transcendence of an ideal society based on self-denial. Their vertical position seems to indicate that the martyr is not passive in death but rather the active witness of a higher cause. The bloodied shrouds form the background while an immaculate white shroud bearing a sword with a bloodstained tip is positioned in the foreground. The shrouds cover headless bodies. This incomplete presence of the body, breaking with the normal human form, refers to a traditional representation of the martyr's body in Iranian revolutionary iconography: the headless martyr recalls Imam Husayn, who was beheaded in Karbalā' in 680 (hence the tears at the neckline of the shroud) and whose severed appendage was sent to the Umayyad caliph in Damascus. The flight of the soul is symbolised by the upward movement of a dove taking flight at the bottom of the painting. Although the bird is white, its right wing is also bloodstained. 


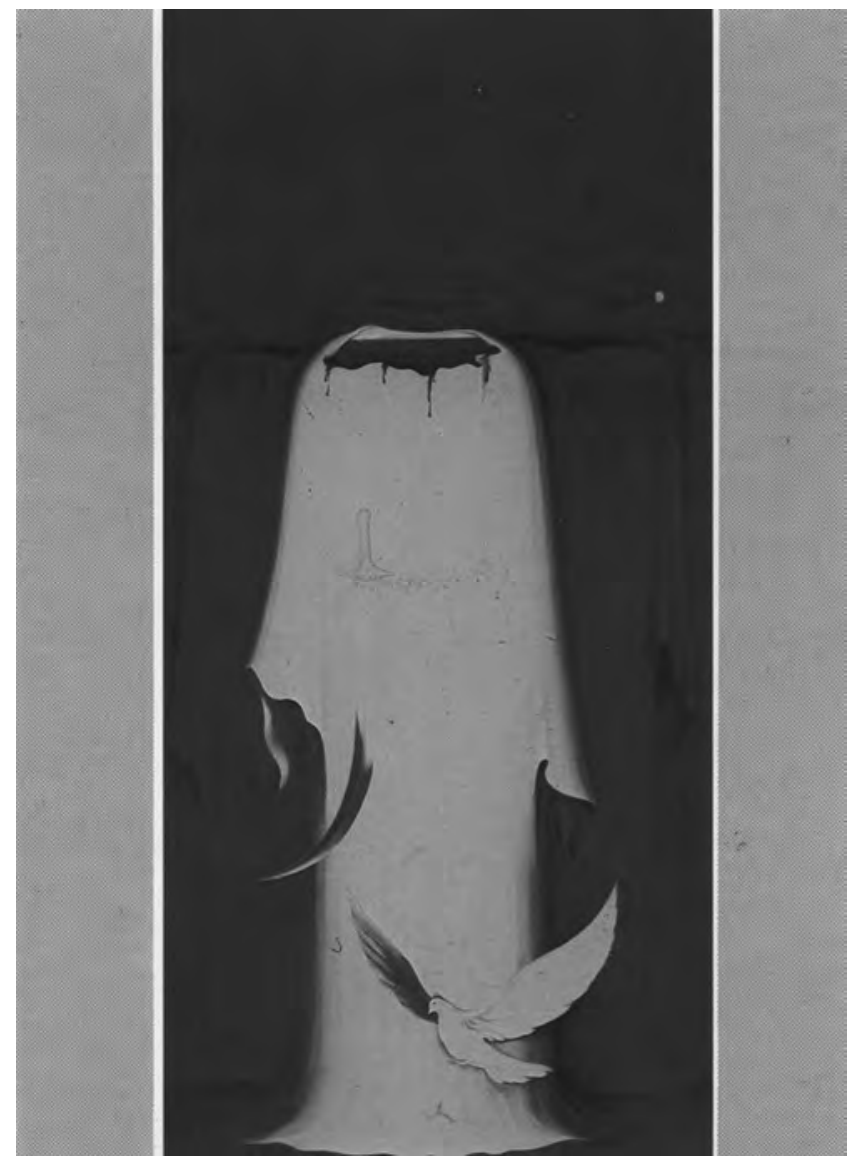

Fig. 3: Nasser Palangi, Shroud of Blood, c.1981 $(300 \times 140 \mathrm{~cm})$

In this painting, the abstract and symbolic dimension of martyrdom predominates. This "community in death" 47 expresses a striving for the ideal society, where martyrs would serve as mediators between the ordinary human reality and the Perfect Man. The predominance of the theme of bloodshed, the depiction of a community of martyrs, as well as the title itself all indicate the gap where ideology emerges. This is a hijacking of religion and an exploiting of art for the purpose of political strategies that promote the repetition of deadly behaviors.

Finally, in his mural painting entitled Self Sacrifice (c. 1981, see fig. 4), full of symbols and structured as a choreography, Kazem Chalipa illustrates the same dimension of martyrdom as shown in Nasser Palangi's work. Martyrdom corresponds here again to the expression of a collective united in common values and faith. A woman dressed in black, her stony face frozen with pain - likely a mother figure - holds a lifeless body covered in a white shroud. She is located in

47 Khosrokhavar, L'islamisme et la mort, 292. 


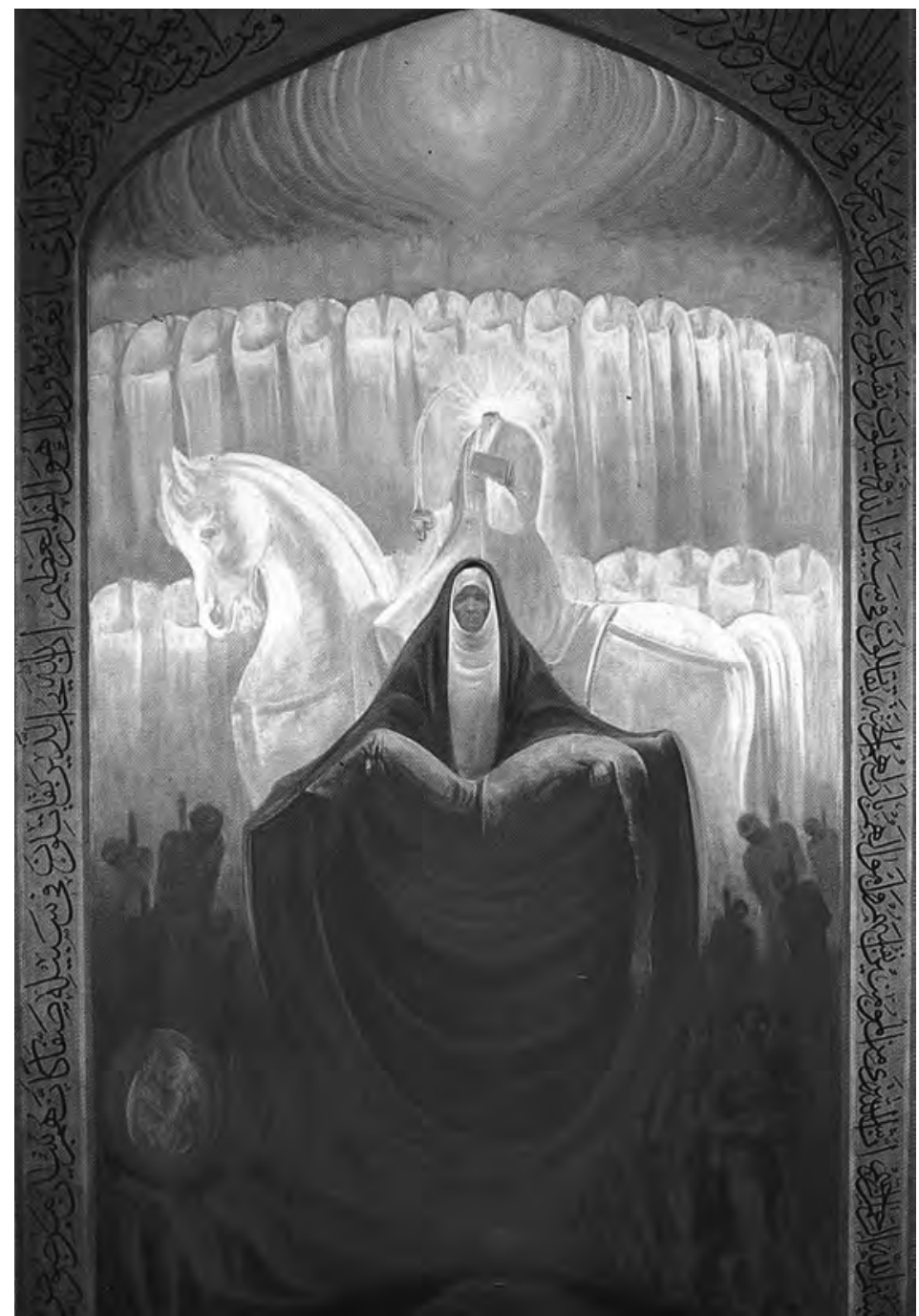

Fig. 4: Kazem Chalipa, Self Sacrifice, c. $1981(300 \times 200$ cm $)$

the centre of the painting and serves to separate two distinct areas, one above her where the colour white prevails and the other below her, bathed in a glowing red atmosphere. To her right, a long line of the dead man's comrades-in arms and co-religionists moves forward with rifles in hand. To her left, a perfectly symmetrical row of red tulips, symbols of martyrs, moves toward the viewer. In the first flower, the semi-transparent petals reveal at their heart a golden light, and a kind of embryo of a future martyr. At the bottom of the painting, we perceive the outline of a grave where another red tulip seems rooted. Its vast corolla forms an altar supporting the arms of the woman who is carrying the body of the martyr as an offering. Above the two symmetrical processions, twisted figures of tor- 
tured or shot men attached to posts bring forth the image of an excruciating conflict. In the upper portion of the painting where the colour white prevails, we can identify behind the woman the figure of Imam Husayn riding a white horse. Paragon of the martyr in Shiism, Imam Husayn wears a dark grey coat over his shroud. Instead of a head, however, a circle of light emanates from his neck. He holds a book, the Koran most likely, in his left hand and a sword in the right. Beyond him, occupying the upper third of the work, two distinct rows of beheaded martyrs face the viewer. These spectra, representing perhaps his seventytwo companions, wait with serenity for Judgment Day. At this level of reading, the figure of the Imam of Time, who it is thought will appear at the end of time on a white horse, seems to be superimposed on the figure of Imam Husayn. ${ }^{48}$ In the middle of the upper portion of the painting, a light seems contained in white petals, which conjures up once again the form of a tulip outlining the sky. At the heart of this light, a closed hand appears with its forefinger pointing upward in the direction of Heaven. Finally, the painting (mural) is framed by religious calligraphic writing in the shape of a doorway or threshold.

In this fourth and last painting, martyrdom is already accomplished, the "door" crossed. The martyr is encircled in a multitude of symbolic, religious, and collective references. He is part of a larger configuration to which he contributes and brings his blood, but which revolves around him. The divine hand pointing in the direction of Heaven seems to pull the world upwards; at the same time, however, the reality of suffering and war is not obscured but rather is reflected on the stony face of the woman. The assassination of Karbalā' which is a foundation of Shiism, is mentioned here not merely as an example to follow, that of "self-sacrifice", but as a struggle for faith to be practiced alongside the Imam, the incarnation of the Perfect Man in the first Shiite sources. ${ }^{49}$

These paintings of the early 1980s featured the repeated representation, or indeed the overexposure, of the martyr's body, which became a new symbol of martyrdom. ${ }^{50}$ To this point, the personal fate of the martyr within the context of the battle is ignored. Instead, emphasis is placed on the dying or dead body that reflects the accomplished sacrifice and becomes the subject of celebration. Martyrdom as staged in these paintings makes reference to the founding elements of the Shiite religion and its theological particularities: the revolt of Imam Husayn, the eschatological expectation of the Savior Imam, the Last Judgment as justification for rebellion against an unjust authority, the wait for the great revolution of the end of time, and the triumphant return of the Twelfth Imam and advent of his kingdom of justice and truth. It is also staged through the mediation of an

48

49 tradition et idéologisation", in: Les retours aux écritures: fondamentalismes présents et passés, ed. by Evelyne Patlagean et al., Louvain et al.1993, 68.

50 
edifice of signs and symbols. What appears emphatically as a leitmotiv is related to bereavement and mourning. The grief that follows the martyr's death is ritualised and established as a cult. Death as martyr, central in these four paintings, appears in glorious veneer as an ideal to achieve, as a means to transcendence and divine perfection.

In these paintings, the notion of the Perfect Man is associated with what is identified as a deadly vision of religion: the pursuit of perfection in death is achieved when the individual is driven by a yearning for martyrdom. The martyr in his journey towards death, a hallmark of revolutionary thought, is rightly described by Farhad Khosrokhavar as the "Pilgrim of the Absolute". ${ }^{51}$ The notion of the Perfect Man is superimposed on the figure of the martyr, in the sense that the martyr accepts to the point of death the role of protector of faith, as well as the role of Revelation destined to the Perfect Man.

The reformulation of the mystical notion of the Perfect Man highlighted here gives a privileged status to the martyr, who becomes a kind of prototype of the Perfect Man. The frequent declarations by Ayatollah Khomeini on the subject are particularly instructive. In 1982, in a message to families of martyrs, he declared: "Martyrdom in the way of God is not something that can be evaluated with human criteria and tangible objectives [...] because the great value and higher status of martyrdom need divine criteria. We, earthly creatures, are quite incapable and the heavenly creatures are also unable to grasp the essence of martyrdom, because it is part of the attributes of the Perfect Man [...]. Martyrs are beyond our understanding". ${ }^{52}$ Earlier, in 1981, inside the walls of the Foundation of Martyrs, his declaration was even more acute: "In the tradition reported in the $K \bar{a} f i,{ }^{53}$ the same rank is given to the prophets and to the martyrs, so that the glory expressed for the prophets is the same that is shown to the martyrs. The martyr also contemplates the face of God; he tears the veil in the same way that prophets have torn theirs, and this is the last stage permitted for a man to achieve. We were promised that, for the martyrs, it would be the same stage as for the prophets". 54

Ayatollah Khomeini explicitly uses here the notion of the Perfect Man to root the rhetoric of martyrdom in revolutionary Shiite ideology. By comparing the martyr to the Perfect Man and the prophets, he fills the desire for recognition and promotion of the young soldiers that the Islamic regime encouraged, both on the domestic scene and on the front of the Iran-Iraq War, and continues to encourage them to sacrifice themselves on behalf of the ideals of the Revolution.

51 Khosrokhavar, L'Islamisme et la mort, 294.

52 Ruhollah Khomeini, "Message aux familles de martyrs, prisonniers, disparus, invalides et blessés, 31 Shahriwar 1362-22 Septembre 1983”, in: Șaḩifih-yi Nūr 18, 119.

53 The book Al-Käfif fi 'ilm al-din (What is Sufficient in the Knowledge of the Faith) is a Twelver Shiite Hadith collection compiled by Muhammad Ya'qūb Kulaynī.

54 Ruhollah Khomeini, "Message à un groupe de responsables de la Fondation des Martyrs, 20 dey 1359-10 Janvier 1981", in: Șậifih-yi Nūr 13, 272-274. 
Ibn al-'Arabì described the paths that lead to the Perfect Man; among them, martyrdom is not mentioned. ${ }^{5}$ Similarly, Ali Shariati did not cite the model of the martyr as a possible incarnation of the Ideal Man. In his Islamology, he developed an ideal of life and not of death: "[The Ideal Man] seeks out mankind and thus attains God. He does not bypass nature and turn his back on mankind". ${ }^{56}$ Under the auspices of revolutionary Shiite ideology, a semantic mutation of the notion was carried out. The idea of the Perfect Man was turned into a model of perfection via martyrdom. This mutation is closely related to Islamic mysticism, according to which the Perfect Man has attained the state of fan $\bar{a}$, the state of "mystical death". Yet, in revolutionary Shiite ideology, this mystical concept is redefined and reassessed. The mystical state of death is explicitly transformed into a state of physical death. In other words, real death is permitted and sanctified by the notion of martyrdom, and self-sacrifice is de-ritualised. ${ }^{57}$

Examining Indo-Muslim literature dating from the late $13^{\text {th }}$ century, Annemarie Schimmel has commented on the connection made between the formula insān-i kāmil = shabìd and fana $\bar{a}=$ shabādat, as in for example the poetry of Shāh 'Abd alLațîf of Bhit (1689-1752). ${ }^{58}$ As she notes, Shāh 'Abd al-Latịif explicitly specified that the heroes of his work, "who ha[d] never thought themselves, but only of love of God which makes them face all difficulties, ha[d] finally reached the goal: the fan $\vec{a}^{\prime}$ fi'lläh, annihilation in God and remaining in Him". ${ }^{99}$ According to her, the poet had transformed the life of the Imams, and the death of the Imam Husayn in particular, into "a model for all those Sufis who strive [...] to reach the final annihilation in God, the union which the Sufis so often express in the imagery of love and loving union". ${ }^{60}$ If a link between Imam Husayn's martyrdom (shabādat) and the mystical death (fan $\bar{a})$ was metaphorically (yet explicitly) extended in the poetic work of this author, in the Shiite revolutionary apparatus sacrificial death is henceforth concretely demanded in service of the regime's interests.

\section{Conclusion}

In an article about the historical evolution of Shiism, Mohammad Ali AmirMoezzi shows how Twelver Shiism after the Islamic Revolution in Iran became "one of the most politicised variants of Islam, a doctrine seeking to build an ideology of salvation, ideology taken in a political sense". ${ }^{61} \mathrm{He}$ explores how this trans-

\footnotetext{
Takeshita, “The Theory of the Perfect Man in Ibn 'Arabī’s Fuṣūs al-Hikam”, 87-102.

Shariati, On the sociology of Islam, 122.

Halm, Shic Islam, 136.

58 Annemarie Schimmel, "Karbalā' and the Imam Husayn in Persian and Indo-Muslim Literature”, in: Al-Sirāt, 12 (1984), 29-42.

59 Ibid, 29-42.

60 Ibid, 29-42.

61 Amir-Moezzi, "Réflexions sur une évolution du shi’isme duodécimain”, 63.
} 
formation of the traditional Shiite religion can be related to the historical evolution of its dogma. While in the original context of Shiism the term 'älim (singular of 'ulam $\bar{a}$ ), translated as "wise initiate", was exclusively reserved for the Imam, this term from the late ninth century was synonymous with jurist-theologian. ${ }^{62}$ At the same time, esoteric traditions with a metaphysical and mystical dimension were progressively rejected. From the Būyid dynasty, the "theological-legal rational tradition" emerged gradually as the mainstream of Twelver Shiism, relegating the "esoteric non-rational tradition" to an increasingly marginalised position. ${ }^{63}$ Khomeini's doctrine and its central theory of the "power of the jurist-theologian" (wilayyat-i faqīh) should be contextualised in this historical and doctrinal evolution of Shiism. According to M. A. Amir-Moezzi, it can be regarded as the logical result of a process which ran during almost a millennium, from the divine wisdom of the Imam to rationalisation and finally to "ideologisation". ${ }^{64}$ Even if regarded as a potential historical phenomenon, he nonetheless assesses this final stage ("ideologisation") as a revolution in traditional Shiism. ${ }^{65}$ Said Amir Arjomand also conceives the faqūh-system as a deviation from classical Shiism, ${ }^{66}$ in the same way that the political revolutionary interpretation of the tragedy of Karbalā' is considered by Heinz Halm as a new step in twentieth century Shiism. ${ }^{67}$

From his book published in 1944, The Discovery of Secrets, Ayatollah Khomeini's doctrine became increasingly important ${ }^{68}$ Ali Shariati participated in its strengthening by focusing his own thinking, from the late 1960s, on the political and ideological dimension of Islam. The revolutionary Shiite ideology of the 1980s, however, came to differ from the classic casuistry by inserting extremely simplified mystical concepts such as the Perfect Man. As explained by Amir-Moezzi, the rational theological tradition as opposed to the mystical tradition historically gained ground and culminated with the coming to power of Ayatollah Khomeini. ${ }^{69}$ However, as shown in this work, revolutionary Shiite ideology as driven by the search for charisma presents the particularity of re-use and reformulation of certain mystical aspects of Shiite belief in order to accentuate influence and consolidate its power.

Aware of the impact of these reformulations, Ayatollah Khomeini encouraged many actors within the political scene, not just the 'ulam $\bar{a}$ ', to spread the revolutionary ideology. Both through their discourse and their works, the committed painters formed part of the eulogists of revolutionary Shiism. Through a comprehensive approach, I have correlated the discourse of three of these revolu-

\author{
Ibid, 68-73. \\ Ibid, 71. \\ Ibid, 79. \\ Ibid, 63. \\ Said Amir Arjomand, The Turban for the Crown, Oxford 1988, 177-88. \\ Halm, Shica Islam, 137. \\ 8 Ruhollah Khomeini, Kashf al-Asrār, Tehran 1944. \\ 69 Amir-Moezzi, "Réflexions sur une évolution du shi'isme duodécimain", 78-81.
}


tionary artists interviewed in 2009 with the analysis of paintings created in the early 1980 s by the same narrow circle of committed artists.

For each of the three artists, it was paramount that the interview conveys their commitment to the ideals of the Islamic regime and to God. Their discourse reveals how the painting of martyrs was rooted in the revolutionary event, which is considered sacred by having potentially initiated the advent of a new world ruled by the mystical criterion of the Perfect Man. However, the revolutionary Shiite rhetoric - despite having constructed inter-human links and a closer relation to God - became blunt in its confrontation with the harsh reality and as a result of disillusionment.

The Perfect Man makes what God appreciates. How can we achieve him? I thought that in a short period the world could change. But I got the idea that it does not happen like that. It was necessary to apply these principles in our own society. And it is already difficult. (Mr. R, 2009)

In 2009, the three painters finally confided that they had distanced themselves from their first matrix.

Through the discourse of these painters, it appears that the mystical notion of the Perfect Man, whose use was recurrent during the interviews, constitutes a key concept of revolutionary Shiite ideology. They frequently used the notion and applied it in their own field to describe the artist worthy of the name. Painting was first understood by these three artists as a privileged vector to complete political commitment and to a pure faith, which thus placed them on a path to a higher level of humanity as embodied by the Perfect Man. Within the CTIA, the committed artists sought confirmation of their legitimacy through Ali Shariati's ideology. The reformulation of the notion of the Perfect Man as applied to their own group allowed these artists to rise socially, as well as to insert and legitimise - for their benefit but also at their expense - art and artistic practice in the Islamic regime.

Finally, through the four paintings of martyrs analysed here, another ideological reformulation of the Perfect Man emerges in a vision of perfection culminating in death. Between 1980 and 1983, in the CTIA and Sürih University, revolutionary painting was devoted, tirelessly, to the glorification of martyrdom. The force of persuasion that these paintings conveyed in the 1980s resulted partly from the mystical ideal of the Perfect Man in which they were rooted. The revolutionary painters translated through their art a political and religious utopia. The martyr, one of the main symbols of this utopia, conveyed hidden and esoteric truth that could only be achieved through death and that could, in turn, transform society.

Through these discourses and artistic works, the mystical notion of the Perfect Man, reformulated at several levels, can be considered an essential part of a broader ideological framework. This complex ideological apparatus succeeded in linking traditional mystical concepts, revolutionary Shiite ideology, and figurative representation, all in support of Ayatollah Khomeini's doctrine and the larger project of the Islamic Revolution. 